\title{
Response of Scots pine (Pinus sylvestris L.) and pubescent oak (Quercus pubescens Willd.) to soil and atmospheric water deficits under Mediterranean mountain climate
}

\author{
Rafael Poyatos ${ }^{1,2 *}$, Pilar Llorens ${ }^{1}$, Josep PiÑOL ${ }^{3}$, Carles RUBIO ${ }^{1,4}$ \\ ${ }^{1}$ Institute of Earth Sciences 'Jaume Almera' (CSIC), Lluís Solé Sabarís s/n, 08208 Barcelona, Spain \\ ${ }^{2}$ Present address: Solfranc Tecnologiás, S.L., Horta Novella 24, 43480 Vilaseca, Tarragona, Spain \\ ${ }^{3}$ Ecology Unit and CREAF, Facultat de Ciències, Universitat Autònoma de Barcelona, 08193 Bellaterra, Spain \\ ${ }^{4}$ Present address: Lab Ferrer, UPC, Campus Baix Llobregat, Av. Canal Olímpic 15, 08860 Castelldefels, Spain
}

(Received 30 March 2007; revised version 25 July 2007; accepted 30 October 2007)

\begin{abstract}
The physiological responses to water deficits of Scots pine (Pinus sylvestris L.) and pubescent oak (Quercus pubescens Willd.) were studied under Mediterranean mountain climate. Minimum leaf water potentials were $-3.2 \mathrm{MPa}$ for oak and $-2.1 \mathrm{MPa}$ for pine, with higher predawn values for pubescent oak. Relative sap flow declined in both species when vapour pressure deficit $(D)$ went above ca. $1.2 \mathrm{kPa}$, but stomatal control was stronger for pine during the 2003 summer drought. P. sylvestris plant hydraulic conductance on a half-total leaf area basis $\left(k_{\mathrm{L}, \mathrm{s}-1}\right)$ was $1.2-2.6$ times higher than the values shown by $Q$. pubescens, and it showed a considerably steeper decrease during summer. Leaf-level gas exchange was positively related to $k_{\mathrm{L}, \mathrm{s}-1}$ in both species. Scots pine was more vulnerable to xylem embolism and closed stomata to prevent substantial conductivity losses. The results of this study confirm that pubescent oak is more resistant to extreme drought events.
\end{abstract}

canopy stomatal conductance / drought / hydraulic conductance / Mediterranean climate / sap flow

Résumé - Réponses du pin sylvestre (Pinus sylvestris L.) et du chêne pubescent (Quercus pubescens Wild.) aux déficits hydriques atmosphérique et édaphique sous climat montagnard méditerranéen. Les réponses physiologiques aux déficits hydriques du pin sylvestre (Pinus sylvestris L.) et du chêne pubescent (Quercus pubescens Wild.) ont été étudiées sous climat montagnard méditerranéen. Le potentiel hydrique foliaire minimum atteint a été de -3,2 MPa pour le chêne et de -2,1 MPa pour le pin, avec des valeurs de potentiel de base plus élevées pour le chêne pubescent. Un relatif déclin du flux de sève a été observé chez les deux espèces lorsque le déficit de vapeur d'eau dépassait $1,2 \mathrm{kPa}$, mais le contrôle stomatique a été plus fort chez le pin pendant la sécheresse de l'été 2003 . La conductance hydraulique des pins, ramenée à la surface foliaire $\left(\mathrm{k}_{\mathrm{L}, \mathrm{s}-1}\right)$ a été de 1,2 à 2,6 fois plus élevée que celle de Quercus pubescens et a présenté une rapide décroissance pendant l'été. Le niveau des échanges gazeux foliaires était positivement corrélé à $\mathrm{k}_{\mathrm{L}, \mathrm{s}-1}$ chez les deux espèces. Le pin sylvestre est plus vulnérable à l'embolie du xylème et a de ce fait fermé ses stomates pour empêcher une perte substantielle de conductivité hydraulique. Les résultats de cette étude confirment que le chêne pubescent est plus résistant aux épisodes d'extrême sécheresse que le pin sylvestre.

conductance stomatique du couvert / sècheresse / conductance hydraulique / climat méditerranéen / flux de sève

\section{INTRODUCTION}

Scots pine (Pinus sylvestris L.) and pubescent oak (Quercus pubescens Willd.) are two of the most representative tree species in mountain areas of NE Spain. While Scots pine is a Eurosiberian species with a broad distribution, pubescent oak, restricted to southern Europe, occupies the transition zone between Mediterranean-type and more humid environments [23].

Although both species coexist, they differ in the main morphological traits of the water transport pathway from roots to leaves. Scots pine is an evergreen conifer, with tracheidbearing xylem and pubescent oak is a winter deciduous or marcescent broadleaved species, with ring-porous xylem. Due to its tracheid xylem anatomy, Scots pine shows a very low

*Corresponding author: rafa.poyatos@solfranc.com sapwood conductivity, as generally observed in conifers [34], but it also has very low leaf-to-sapwood area ratios $\left(A_{L}: A_{S}\right)$ compared to other pine species [15]. The contrary usually holds for deciduous oak species, which show higher efficiency of the conducting elements and higher $A_{L}: A_{S}$ [46]. These contrasting combinations of traits may result in a similar hydraulic sufficiency at the whole-plant level [3].

With regard to water economy strategies, Scots pine closes stomata when soil moisture deficit has reached a specific threshold [22] whereas pubescent oak maintains high transpiration rates despite the incidence of drought [32], partly due to the ability to extract water from deep soil layers and groundwater [45]. While Scots pine is relatively vulnerable to embolism [11], and accordingly, shows a tight stomatal control [22] published studies suggest a comparatively less tight control in $Q$. pubescens [14]. 
Trees adjust their transpiration rates to the capacity of the hydraulic system to supply canopy leaves with water by means of a close coordination between hydraulic and stomatal conductance, which can result in similar responses to environmental conditions across co-existing species [30]. Recent studies on co-occurring Scots pine and pubescent oak have shown slightly higher water deficits in the former species [49]. Indeed, there is increasing evidence that extreme drought episodes affect Scots pine particularly [28], while deciduous oaks like for instance Quercus petraea (Matt.) Liebl., seem unaffected [26].

In this study we compare the physiological response of these two species under the Mediterranean mountain climate coexisting under the Mediterranean mountain climate of the Eastern Pyrenees. Particularly, the aims of our study were: (1) to find whether P. sylvestris shows a tighter stomatal control under limiting conditions of water supply, (2) to investigate differences in stomatal dynamics and its relation to water potential and hydraulic conductance across both species, and (3) to examine the relevance of stomatal control of xylem embolism, especially in P. sylvestris, given the importance of this species in Mediterranean mountain landscapes.

\section{MATERIAL AND METHODS}

\subsection{Study sites}

The two experimental plots are part of the Vallcebre research area $\left(42^{\circ} 12^{\prime} \mathrm{N}, 1^{\circ} 49^{\prime} \mathrm{E}\right)$, located in the Eastern Pyrenees (NE Spain). Climate is sub-Mediterranean, with an average air temperature of $7.3^{\circ} \mathrm{C}$ (measured at 1440 m.a.s.l.) and $924 \mathrm{~mm}$ of annual rainfall [16]. The present landscape is mainly a mosaic of mesophilous grassland of the Aphyllantion type and Scots pine forests, which colonised old agricultural terraces after their abandonment [37]. The extension of pubescent oak forests in the area has been reduced to small patches in unfavourable locations, although it is frequent to find $Q$. pubescens saplings in the undergrowth of Scots pine stands [13].

The Scots pine plot is located in an abandoned terraced slope, at an elevation of $c a .1260$ m.a.s.l. The understorey is scarce, mainly scattered Buxus sempervirens L. shrubs and a discontinuous herb layer. Stand density and basal area are 2165 trees ha $^{-1}$ and $44.7 \mathrm{~m}^{2} \mathrm{ha}^{-1}$, respectively. Mean diameter $( \pm \mathrm{SE})$ at breast height $(\mathrm{DBH})$ is $15.0 \pm$ $0.7 \mathrm{~cm}$ and projected leaf area index (LAI) is $2.4 \mathrm{~m}^{2} \mathrm{~m}^{-2}$. Mudstone and sandstone are the principal underlying lithologies, originating sandy-loam soils about $65 \mathrm{~cm}$ deep (Rubio, unpublished results).

The oak plot is located just $0.8 \mathrm{~km}$ apart from the pine plot, and it is characterised by a lower tree density $\left(828\right.$ trees ha $\left.^{-1}\right)$, lower LAI $\left(2.1 \mathrm{~m}^{2} \mathrm{~m}^{-2}\right)$, and the presence of a dense and species-rich understorey with other tree (Prunus avium L., Fraxinus excelsior L., Acer campestre L.) and shrub species (Buxus sempervirens L., Prunus spinosa L., Rubus spp. and Rosa spp.). Trees are larger than in the pine plot (mean tree diameter of $21.1 \pm 1.4 \mathrm{~cm}$ ), but oak basal area, which represents $99 \%$ of total tree basal area, is lower $\left(32.5 \mathrm{~m}^{2} \mathrm{ha}^{-1}\right)$. The upper soil, which is formed by a loamy matrix and limestone blocks, is about $50 \mathrm{~cm}$ deep [39].

\subsection{Meteorological and soil moisture measurements}

Above-canopy meteorology, soil moisture and sap flow were measured continuously between May 2003 and August 2005. Detailed information on the meteorological monitoring can be found in recent publications about research carried out in the same experimental plots [36].

Soil moisture in the top $30 \mathrm{~cm}$ was measured continuously with vertically installed water content reflectometers (CS615-CS616, Campbell Scientific, Leicester, Leicestershire, UK). Both probes were calibrated using weekly measurements of soil water content with the TDR technique (Tektronix 1502C, Beaverton, Oregon, USA) in the vicinity of the reflectometer, and corrected for soil temperature effects. Weekly manual measurements of soil moisture began in June 2003 in both plots, whereas continuous monitoring began in June 2003 in the pine plot and May 2004 in the oak plot. To account for the spatial variability of soil moisture the output from both reflectometers was related to an average weekly measurement of soil moisture in each plot, obtained from 4 and 5 TDR probes located randomly in the pine and the oak plots, respectively. The resulting linear relationships were used to estimate an average soil moisture value for each stand. Additional soil moisture measurements were taken with two vertically placed TDR probes at deeper locations in the soil (30$60 \mathrm{~cm}$ in the pine plot and $30-50 \mathrm{~cm}$ in the oak plot, respectively).

A water retention curve was constructed from 2-3 unaltered soil samples at each depth interval $(0-5 \mathrm{~cm}, 5-10 \mathrm{~cm}, 10-15 \mathrm{~cm}$ and $25-$ $30 \mathrm{~cm}$ deep), in both monitored plots. Volumetric moisture of soil samples was measured at matric potentials of $-0.25 \mathrm{kPa},-1 \mathrm{kPa}$ and $-3.2 \mathrm{kPa}$ using the sand-box method, and at $-0.1 \mathrm{MPa},-0.32 \mathrm{MPa}$ and $-1.5 \mathrm{MPa}$ using the pressure membrane method [38]. These detailed data were primarily obtained for a parallel investigation on the differences in soil hydraulic properties related to changes in land cover (Rubio 2005). However, here we were interested in converting our soil moisture measurements in the upper $0-30 \mathrm{~cm}$ into soil water potentials averaged over the same depth $\left(\psi_{s, 0-30}\right)$ using soil water retention curves. Therefore we obtained only one curve for each plot calculating first the depth-averaged value of soil moisture at the given suction for the upper $30 \mathrm{~cm}$ (e.g. samples at 10-15 cm and 25-30 cm were assumed to be representative of the $15-20 \mathrm{~cm}$ and $20-25 \mathrm{~cm}$ intervals, respectively). For simplicity, we used the retention curve whose mathematical form fitted best the data, (nonlinear regression, SPSS v.13.0, Chicago, USA), and not a more physicallybased model [47].

\subsection{Sap flow}

In each plot, sap flow was measured with heat dissipation probes [17] manufactured in our lab. Sap flow gauges were installed at breast height, and covered with reflective insulation to avoid the influence of natural temperature gradients in the trunk. A maximum of 12 trees was measured simultaneously (Tab. I). Probes installed in pines were $20 \mathrm{~mm}$ long, whereas those used in oaks were $10 \mathrm{~mm}$ to minimize the errors due to steep gradients in sap flow density along the depth of the sensor [8].

Sap flow measured by Granier sensors was corrected for radial variability in sap flow density as done previously for pubescent oak [36]. Briefly, a multi-point Heat Field Deformation sap flow sensor [31] was used to measure sap flow at five depths and relate the value of sap flux density at each depth to a reference sap flow equivalent to sap flux density measured by the Granier sensor. Then, 
Table I. Trees and periods of sap flow measurements: long-term monitoring with heat dissipation (HD) sensors and radial patterns measurements with heat field deformation (HFD) sensors.

\begin{tabular}{|c|c|c|c|c|c|}
\hline & $\begin{array}{c}\text { Tree } \\
\text { ID }\end{array}$ & $\begin{array}{l}\mathrm{DBH} \\
(\mathrm{cm})\end{array}$ & $\begin{array}{l}\text { Height } \\
(\mathrm{m})\end{array}$ & $\begin{array}{l}\text { Period of HD sap } \\
\text { flow measurements }\end{array}$ & $\begin{array}{c}\text { Period of radial } \\
\text { patterns measurements }\end{array}$ \\
\hline \multirow[t]{13}{*}{ P. sylvestris } & 1 & 6.7 & 6.3 & May 2004-Aug 2005 & \\
\hline & 2 & 10.2 & 11.0 & Jun 2003-Aug 2005 & \\
\hline & 3 & 11.3 & 10.5 & May 2004-Aug2005 & \\
\hline & 4 & 12.7 & 10.5 & May 2004-Aug 2005 & $217-220$ (5-8 Aug)* \\
\hline & 5 & 13.3 & 10.5 & May 2004-Aug2005 & \\
\hline & 6 & 15.9 & 10.5 & Jun2003-Aug 2005 & 203-216 (22 Jul-4 Aug) \\
\hline & 7 & 18.0 & 9.5 & May 2004-Aug 2005 & $196-203$ (15-22 Jul)* \\
\hline & 8 & 19.4 & 13.0 & Jun 2003-Mar 2004 & \\
\hline & 9 & 19.9 & 12.5 & Jun 2003-Aug 2005 & \\
\hline & 10 & 20.4 & 12.5 & Jun 2003-Aug 2005 & $102-110(2-10 \mathrm{Apr})^{*}$ \\
\hline & 11 & 22.5 & 12.5 & May 2004-Aug 2005 & 181-186 (30 Jun-5 Jul)* \\
\hline & 12 & 27.9 & 12.5 & Jun 2003-Aug 2005 & $116-120(26-30 \mathrm{Apr})^{*}$ \\
\hline & 13 & 29.3 & 11.5 & May 2004-Aug2005 & 173-181 (22-30 Jun)* \\
\hline \multirow[t]{12}{*}{ Q. pubescens } & 1 & 8.7 & 7.2 & May 2003-Oct 2004 & $197-199(15-17 \text { Jun })^{* *}$ \\
\hline & 2 & 12.6 & 9.1 & May 2003-Sept 2004 & \\
\hline & 3 & 14.5 & 10.0 & May 2003-Aug 2004 & \\
\hline & 4 & 17.85 & 10.9 & May 2003-Aug 2005 & $203-206(21-24 \mathrm{Jul})^{* *}$ \\
\hline & 5 & 19.2 & 11.2 & May 2003-Nov 2004 & \\
\hline & 6 & 20.9 & 10.5 & May 2003-Aug 2005 & $279-281(5-7 \text { Oct })^{* *}$ \\
\hline & 7 & 21.1 & 11.7 & May 2003-Aug 2005 & $265-267(21-23 \mathrm{Sep})^{* *}$ \\
\hline & 8 & 21.5 & 11.8 & May 2003-Oct 2004 & $272-275$ (28 Sep-1Oct) $^{* *}$ \\
\hline & 9 & 26.2 & 10.0 & May 2003-Aug 2005 & $233-235(20-22 \mathrm{Sep})^{* *}$ \\
\hline & 10 & 26.7 & 14.0 & May 2003-Sept 2004 & $277-279(3-5 \mathrm{Oct})^{* *}$ \\
\hline & 11 & 34.5 & 10.0 & May 2003-Sept 2004 & $269-270(25-26 \mathrm{Sep})^{* *}$ \\
\hline & 12 & 38.2 & 13.0 & May 2003-Sept 2004 & 200-202 (18-20 Jul) $)^{* *}$ \\
\hline
\end{tabular}

* Year 2005; ** Year 2004.

a whole-tree correction coefficient was obtained dividing total sap flow, obtained by adding up sap flow in individual sapwood annuli, by sap flow calculated considering a uniform density profile.

Tree sap flow and leaf gas exchange (see below) were related to half-total leaf area in order to compare both species. To convert $P$. sylvestris projected leaf area to half-total leaf area we multiplied the former by a coefficient of 1.35 [40]. Given that the main purpose of our study was to identify the different responses to varying environmental conditions of pines and oaks, we normalised sap flow per unit leaf area at midday ( $Q_{\mathrm{L}, \mathrm{md}}$ ) with respect to its maximum value [26]. Relative sap flow at midday was then related to vapour pressure deficit $(D)$, net radiation $\left(R_{\mathrm{n}}\right)$ and soil moisture deficit $S M D$, calculated from maximum and minimum values of soil moisture $\left(\theta_{\max }\right.$, $\left.\theta_{\min }\right)[18]$ :

$$
S M D=\frac{\theta_{\max }-\theta}{\theta_{\max }-\theta_{\min }} .
$$

We also calculated canopy stomatal conductance at midday $\left(G_{s, m d}\right)$ derived from sap flow measurements [48], averaging the individual tree values of canopy stomatal conductance $\left(G_{s}\right)$ at the 15-min timestep from 11:00 to 13:00 solar time.

\subsection{Leaf-level gas exchange}

Leaf stomatal conductance to water vapour $\left(g_{s}\right)$ was measured in both species with a portable gas exchange system (LI-6200, LiCor Inc., NE, USA). Six to eight leaves or twigs from the lower canopy were sampled 2-4 times along the day on the 19th-20th May (only in Scots pine), 17th June, 14th-15th July, 4th and 30th August of the year 2005 (DOY 139-140, 168,194-195, 216 and 242).

\subsection{Leaf water potential measurements}

Predawn (2:00-4:00 h, solar time) and midday (11:00-13:00 h, solar time) water potentials were measured in both plots at one date in the year 2003 and every 2-4 weeks during the 2004 and 2005 growing seasons. For each sampling, leaves or twigs from 4-6 trees were sampled with a pruning pole reaching about $4 \mathrm{~m}$ high in the canopy, immediately measuring their water potential with a pressure chamber (PMS Instruments, OR, USA).

\subsection{Vulnerability to embolism in $P$. sylvestris branches}

Additionally, given the dominance of Scots pine forests in the study area, vulnerability to embolism was assessed for this species. A total of 10 mid-crown branches were sampled in August 2004, placed in plastic bags and taken to the lab, where they were stored at $4{ }^{\circ} \mathrm{C}$ during 2 days. Leaves were detached from the branches and their projected leaf area was measured with a leaf area meter (LI-3100, LiCor Inc., NE, USA) Vulnerability to embolism was measured using the air injection method [10]. The branches $(0.6-1.1 \mathrm{~cm}$ in diameter) were cut under water to a final length of ca. $20 \mathrm{~cm}$, and put inside a pressure 


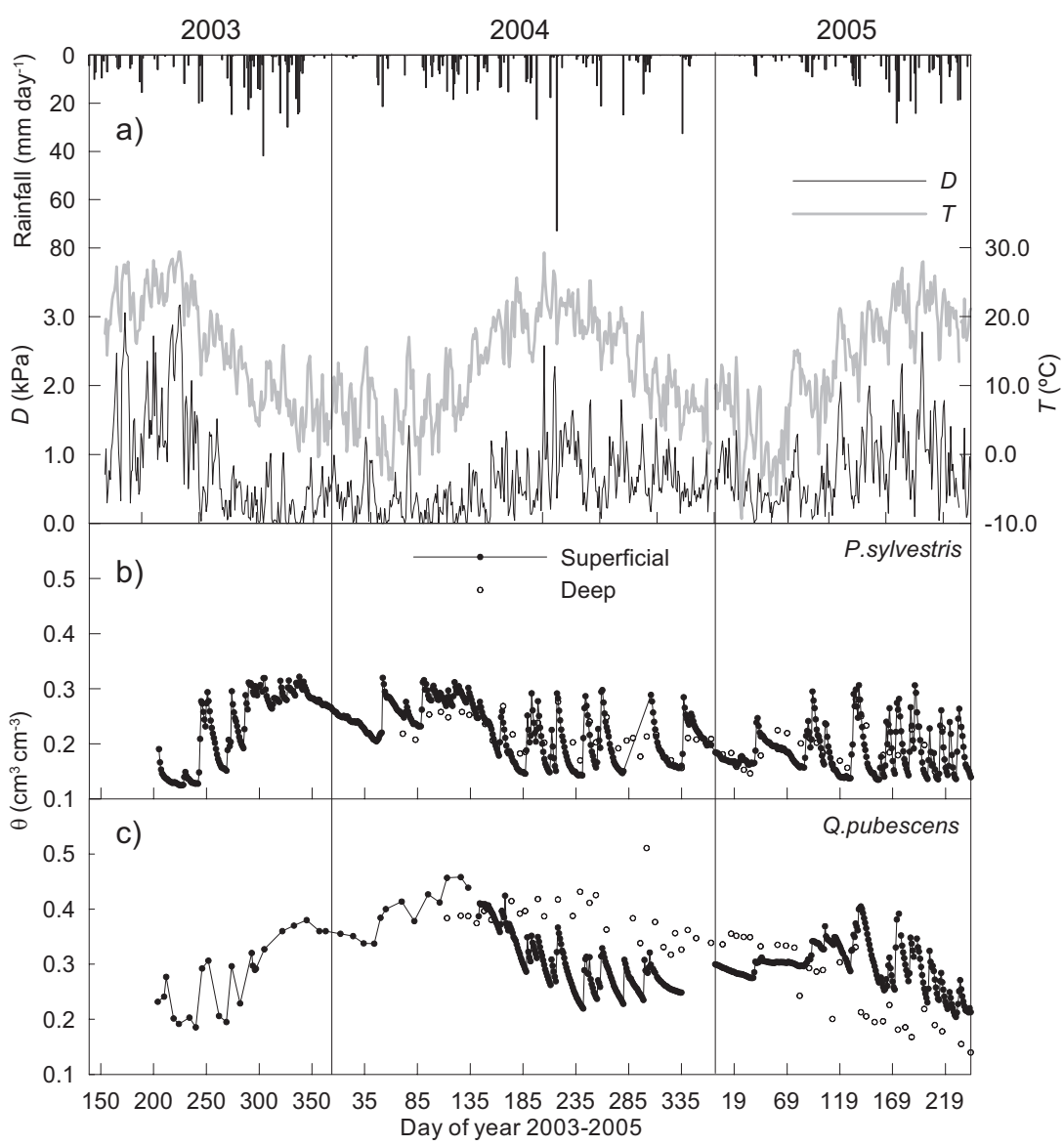

Figure 1. Meteorology and soil moisture during the whole period of study (June 2003-August 2005). (a) Air temperature (T) and vapour pressure deficit $(D)$ only shown for the pine plot, and rainfall measured in a clearing close to the pine plot. (b, c) Closed dots represent superficial soil moisture $\left(\theta_{0-30}\right)$, measured continuously or weekly (at the beginning of the monitoring period in the oak plot). Open dots correspond to soil moisture in deeper soil layers measured weekly in both plots $\left(\theta_{30-50}\right.$ in the oak plot and $\theta_{30-60}$ in the pine plot).

chamber with both ends protruding. The proximal end was connected to a tubing system filled with a filtered $(\Phi=0.22 \mu \mathrm{m})$ and degassed solution of $\mathrm{HCl}$ ( $\mathrm{pH}$ around 2). This solution was injected at a pressure of $75 \mathrm{kPa}$ during 1 hour to remove all native embolisms. Then, the solution was allowed to flow from the tubing system through the branches, driven by a pressure gradient of ca. $6 \mathrm{kPa}$. Maximum hydraulic conductivity was calculated dividing the flow rate through the segment, measured gravimetrically with a previously weighed vial filled with cotton at the exposed end, by the pressure gradient. The segments were then subjected to a $1 \mathrm{MPa}$ rise inside the chamber and maintained during $15 \mathrm{~min}$. The system was allowed to equilibrate setting the pressure at $25 \mathrm{kPa}$ for $10 \mathrm{~min}$ and then conductivity was measured again. We repeated this process, increasing the injection pressure $1 \mathrm{MPa}$ at each step, until we reached $5 \mathrm{MPa}$.

We calculated the percent loss in conductivity (PLC), with respect to the initial measurement, for each pressure level. Vulnerability to embolism was described by the following function, fitted using nonlinear least squares regression (procedure nls in R Statistical Software, v.2.0.1)

$$
P L C=100 /(1+\exp (a(\psi-b)))
$$

where $b$ is the pressure (MPa) causing a $50 \%$ loss of conductivity and $a\left(\mathrm{MPa}^{-1}\right)$ is related to the slope of the curve. This protocol also allowed us to calculate maximum wood-specific $\left(K_{W}, \mathrm{~m}^{2}\right.$ wood area $\left.\mathrm{MPa}^{-1} \mathrm{~s}^{-1}\right)$ and leaf-specific $\left(K_{L}, \mathrm{~m}^{2}\right.$ leaf area $\left.\mathrm{MPa}^{-1} \mathrm{~s}^{-1}\right)$ conductivities at the branch level from the initial conductivity values divided by branch cross-sectional area or distal leaf area, respectively.

\subsection{Hydraulic conductance}

Whole plant hydraulic conductance $\left(k_{\mathrm{L}, \mathrm{s}-1}, \mathrm{~kg} \mathrm{~m}^{-2} \mathrm{~s}^{-1} \mathrm{MPa}^{-1}\right)$ was calculated from the average value of leaf-area based sap flow rates at midday, between 11:00 and 13:00 solar time $\left(Q_{\mathrm{L}, \mathrm{md}}, \mathrm{kg} \mathrm{m}^{-2} \mathrm{~s}^{-1}\right)$ and soil-to-leaf water potential difference $(\mathrm{MPa})$ :

$$
k_{\mathrm{L}, \mathrm{s}-1}=\frac{Q_{L, m d}}{\psi_{s}-\psi_{l}-\rho g h}
$$

$\psi_{s}$ is soil water potential estimated from predawn leaf water potential corrected for gravity effects, $\psi_{l}$ is obtained from water potential measurements at midday, $g$ is acceleration due to gravity $\left(\mathrm{m} \mathrm{s}^{-2}\right), \rho$ is water density $\left(\mathrm{kg} \mathrm{m}^{-3}\right)$ and $h$ is sampling height $(\mathrm{m})$. 
Table II. Rainfall during the selected periods compared to the longterm average.

\begin{tabular}{lcc}
\hline & \multicolumn{2}{c}{ Rainfall (mm) } \\
\hline \multicolumn{2}{c}{ September*-May } & June-August \\
\hline 2003 & - & 116.0 \\
2005 & 648.0 & 221.0 \\
${ }^{* *}$ Long-term average & 315.6 & 257.0 \\
$(1994-2002)$ & & \\
\hline
\end{tabular}

* Of the previous year; ${ }^{* *}$ Latron et al., [25].

\section{RESULTS}

\subsection{Meteorology and soil moisture during the study period}

Meteorological conditions were very similar in both plots, therefore only the data above the pine stand is shown (Fig. 1). Maximum daytime-averaged air temperatures measured above the pine canopy were recorded during August $2003\left(29.4^{\circ} \mathrm{C}\right)$, whereas the lowest was $-9.3{ }^{\circ} \mathrm{C}$, measured in January 2005 . Summer vapour pressure deficit rose above $3 \mathrm{kPa}$ during the summer of 2003, but very seldom reached $2 \mathrm{kPa}$ in the summer of 2004 (Fig. 1). Total summer rainfall (June-August) was very low for 2003, compared to 2004 and 2005, and well below the long-term average for the same months (Tab. II). An unusually dry period occurred also between September 2004 and April 2005 during which rainfall was only $45 \%$ of the total precipitation during the same period in 2003-2004 (Tab. II).

Water content in the upper $30 \mathrm{~cm}$ of the soil was higher in the oak stand, with a range of $0.19-0.46 \mathrm{~cm}^{3} \mathrm{~cm}^{-3}$, whereas in the pine stand it fell between 0.12 and $0.32 \mathrm{~cm}^{3} \mathrm{~cm}^{-3}$. Rainy periods during autumn and spring lead to a recovery of soil water content after the summer of 2003, but this did not occur after the summer of 2004 (Fig. 1). The declining trend in soil moisture beginning in the autumn of 2004 was particularly appreciable in the oak stand, where it was also noticeable that soil moisture in the deeper soil layers $\left(\theta_{30-50}\right)$ was higher than superficial soil moisture during the summer in 2004, but not in 2005 (Fig. 1).

\subsection{Water potentials}

Predawn leaf water potentials were significantly higher in $Q$. pubescens, for both years 2004 (repeated measures ANOVA or ANOVAr, $P<0.001$ ) and 2005 (ANOVAr, $P<$ $0.001)$. Minimum values were ca. -0.8 and $-0.9 \mathrm{MPa}$ for oak and pine, respectively (Fig. 2a, 2b). On the contrary, midday $\psi_{l}$ was significantly lower in $Q$. pubescens during 2004 (ANOVAr, $P=0.002$ ) and 2005 (ANOVAr, $P<0.001$ ). Minimum $\psi_{1, \text { md }}$ (mean $\pm \mathrm{SE}$ ) was much lower in $Q$. pubescens $(-3.2 \pm 0.11 \mathrm{MPa})$ than in $P$. sylvestris $(-2.1 \pm 0.06 \mathrm{MPa})$. The difference between $\psi_{1, \text { pd }}$ and $\psi_{1 \text {, md }}$ was also significantly different between species for 2004 (ANOVAr, $P<0.001$ ) and 2005 (ANOVAr, $P<0.001$ ). Midday water potential decreased more steeply with decreasing $\psi_{1 \text {, pd }}$ in the oak plot
(ANCOVA, $P<0.001$, Fig. 3a), bringing about a greater increase in water potential difference with decreasing $\psi_{1 \text {, pd }}$ (Fig. 3b). The relationship between $\psi_{1, \text { pd }}$ and $\theta_{0-30}$ (Fig. 3c) was different across plots (ANCOVA, $P<0.001$ ). Water retention curves showed no difference between stands at high water potentials (Fig. 3d). However, at a value of $\psi_{5,0-30}=$ $-1.5 \mathrm{MPa}, \theta_{0-30}$ was $0.07 \mathrm{~cm}^{3} \mathrm{~cm}^{-3}$ higher in the oak stand (Fig. 3d). These differences were related with a finer soil texture in the oak stand (Rubio, personal communication). We did not find a significant relationship between $\psi_{s, 0-30}$ estimated from water retention curves and $\psi_{1 \text {, pd }}$, neither for Scots pine $\left(R^{2}=0.14, P=0.115\right)$, nor for pubescent oak $\left(R^{2}=0.22, P=\right.$ $0.105)$.

\subsection{Sap flow and $\mathbf{G}_{s}$ responses to environmental variables}

Maximum absolute values of midday sap flow rates were $3.6 \cdot 10^{-5}$ and $2.9 \cdot 10^{-5} \mathrm{~kg} \mathrm{~m}^{-2}$ leaf area $\mathrm{s}^{-1}$ for $P$. sylvestris and $Q$. pubescens, respectively. The dynamics of relative sap flow showed that its value measured at midday was higher in $Q$. pubescens when dry conditions occurred. This was the case during two exceptionally dry periods, one in the summer of the year 2003 and the other at the end of the unusual winter and spring drought of the year 2005 (Fig. 4). During the year 2004 , though, the values and the dynamics were very similar in the two species. Sap flow relationships with $D$ and $R_{\mathrm{n}}$ were similar for both species (Fig. 5). A marked decrease in relative sap flow with $D$ above ca. $1.2 \mathrm{kPa}$ was particularly appreciable during the year 2003 (Fig. 5a).

Scots pine relative sap flow also showed a declining trend with $\mathrm{SMD}_{0-30}$ in 2003 and 2005, but not in 2004 (Figs. 5c, 5f, 5i). Only during 2005 a clear decline in oak relative sap flow with $\mathrm{SMD}_{0-30}$ could be also observed (Fig. 5i). Relative sap flow declined linearly in both species with SMD, integrated for the whole soil profile examined $\left(\mathrm{SMD}_{0-60}\right.$ in the pine plot and $\mathrm{SMD}_{0-50}$ in the oak plot), when this SMD was higher than 0.6 ( $P$. sylvestris: $R^{2}=0.58, P=0.004 ; Q$. pubescens: $\left.R^{2}=0.51, P=0.014\right)$. Below this value, no apparent trend was observed. The rate of decline of relative sap flow did not differ between species, since we did not find significant differences between the slopes of the two linear regressions (ANCOVA, $P=0.056$ ).

A more detailed examination of meteorological conditions and the response of $G_{\mathrm{s} \text {, md }}$ to the increased water deficits during the summer of 2003 showed that the ratio of sap flow-derived canopy stomatal conductance at midday between Scots pine and pubescent oak $\left(G_{\mathrm{s} \text {, md }}\right.$ (pine) $\left./ G_{\mathrm{s} \text {, md }}(\mathrm{oak})\right)$, declined with extreme $D$ and $\mathrm{SMD}_{0-30}$ conditions, meaning that, under such circumstances, $G_{\mathrm{s} \text {, md }}$ in pine decreased proportionally more than in oak (Fig. 6). After substantial precipitation (> $40 \mathrm{~mm})$, the subsequent refilling of soil water reserve caused pine $G_{\mathrm{s}, \mathrm{md}}$ to increase more than oak $G_{\mathrm{s}, \mathrm{md}}$, as revealed by the increase in the calculated ratio $G_{\mathrm{s} \text {, md }}$ (pine) $/ G_{\mathrm{s} \text {, md }}$ (oak) (Fig. 6).

The values of $G_{\mathrm{s}, \text { md }}$ were higher for Scots pine, although beyond predawn water potentials of $-0.8 \mathrm{MPa}$, Scots pine $G_{\mathrm{s}, \text { md }}$ was reduced to $10 \%$ of its maximum value (Fig. 7a) 


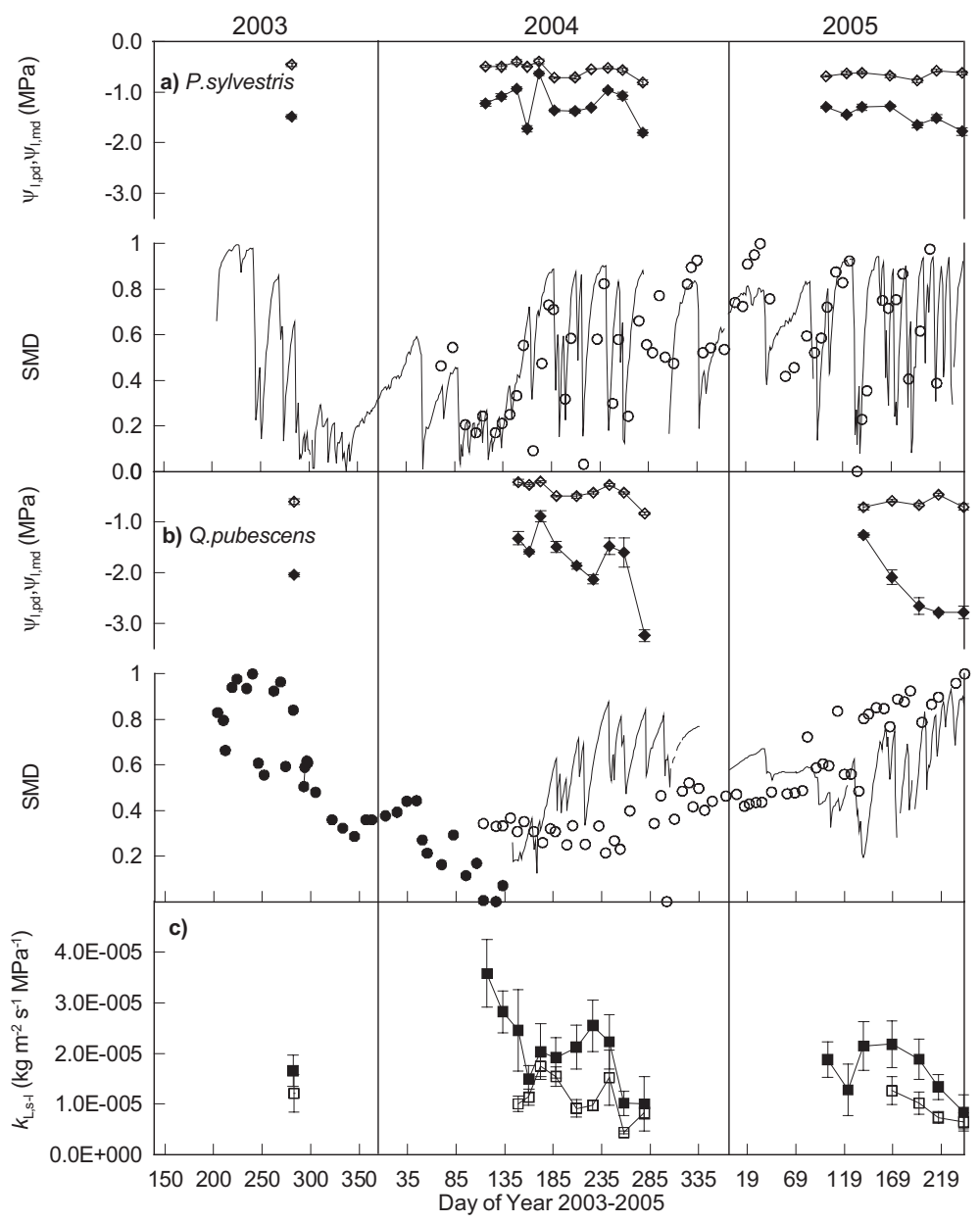

Figure 2. Seasonal evolution of predawn ( $\psi_{1, \mathrm{pd}}$, open symbols) and midday ( $\psi_{l, m d}$, closed symbols) leaf water potentials in (a) Pinus sylvestris and (b) Quercus pubescens, together with soil moisture deficit (SMD) values estimated at the two depths where soil moisture was measured (0-30 cm and 30-50 cm (oaks), 30-60 cm (pines)). (c) Whole-plant hydraulic conductance $\left(k_{\mathrm{L}, \mathrm{s}-1}\right)$ expressed on a leaf area basis is also shown for $P$. sylvestris (closed squares) and $Q$. pubescens (open squares).

while pubescent oak kept $G_{\mathrm{s}, \mathrm{md}}$ around $30 \%$ of its maximum within a range of $\psi_{l, p d}$ from -0.4 to $-0.8 \mathrm{MPa}$ (Fig. $7 \mathrm{~b}$ ).

\subsection{Hydraulic conductance}

Whole plant hydraulic conductance on a leaf area basis $\left(k_{\mathrm{L}, \mathrm{s}-1}\right)$ was ca. $1.2-2.6$ times greater in P. sylvestris than in $Q$. pubescens, although the seasonal dynamics was similar for both species (Fig. 2c). Scots pine $k_{\mathrm{L}, \mathrm{s}-1}$ decreased gradually from spring to summer in 2004. For 2005, however, springtime values were much lower than values for the same period in 2004. Pubescent oak $k_{\mathrm{L}, \mathrm{s}-1}$ showed similar values across years. Scots pine $k_{\mathrm{L}, \mathrm{s}-1}$ was negatively correlated with $\operatorname{SMD}_{0-30}\left(R^{2}=0.46, N=19, P=0.002\right)$, but we did not observe a significant relationship for pubescent oak $\left(R^{2}=0.24, N=14, P=0.080\right)$. However, this lack of fit was driven by two data points, very close to the dates of leaf unfolding (DOY 149 and 160). Disregarding these data, a significant fit emerged $\left(R^{2}=0.57, N=14, P=0.002\right)$.

\subsection{Vulnerability to embolism and relationships between hydraulic conductance and gas exchange}

The parameters (nonlinear regression estimate $\pm \mathrm{SE}$ ) of the vulnerability to embolism curve (Eq. (2), Fig. 8a) for $P$. sylvestris were $a=1.17 \pm 0.13 \mathrm{MPa}^{-1}$ and $b=2.78 \pm$ $0.11 \mathrm{MPa}$ (pressure causing a $50 \%$ loss of xylem conductivity). Maximum levels of wood-specific and leaf-specific hydraulic conductivities measured at the branch level were $K_{W}=4.4 \cdot 10^{-4} \pm 0.74 \cdot 10^{-4} \mathrm{~m}^{2}$ wood area $\mathrm{MPa}^{-1} \mathrm{~s}^{-1}$ and $K_{\mathrm{L}}=2.7 \cdot 10^{-7} \pm 0.27 \cdot 10^{-7} \mathrm{~m}^{2}$ projected leaf area $\mathrm{MPa}^{-1} \mathrm{~s}^{-1}$, respectively. Combining the measured leaf water potentials (Fig. 2a) and the information from the vulnerability curves (Fig. 8a), we observed that the maximum predicted PLC in the field approached $30 \%$. Contrastingly, according to the vulnerability curve by [9], pressure causing a 50\% loss of xylem conductivity in $Q$. pubescens was ca. $-3.4 \mathrm{MPa}$ (Fig. 8b).

P. sylvestris showed reductions of $G_{\mathrm{s}, \mathrm{md}}$ to less than $10 \%$ of its maximum value when leaf water potentials fell beyond $-2.0 \mathrm{MPa}$, meaning a $30 \%$ of xylem conductivity losses 

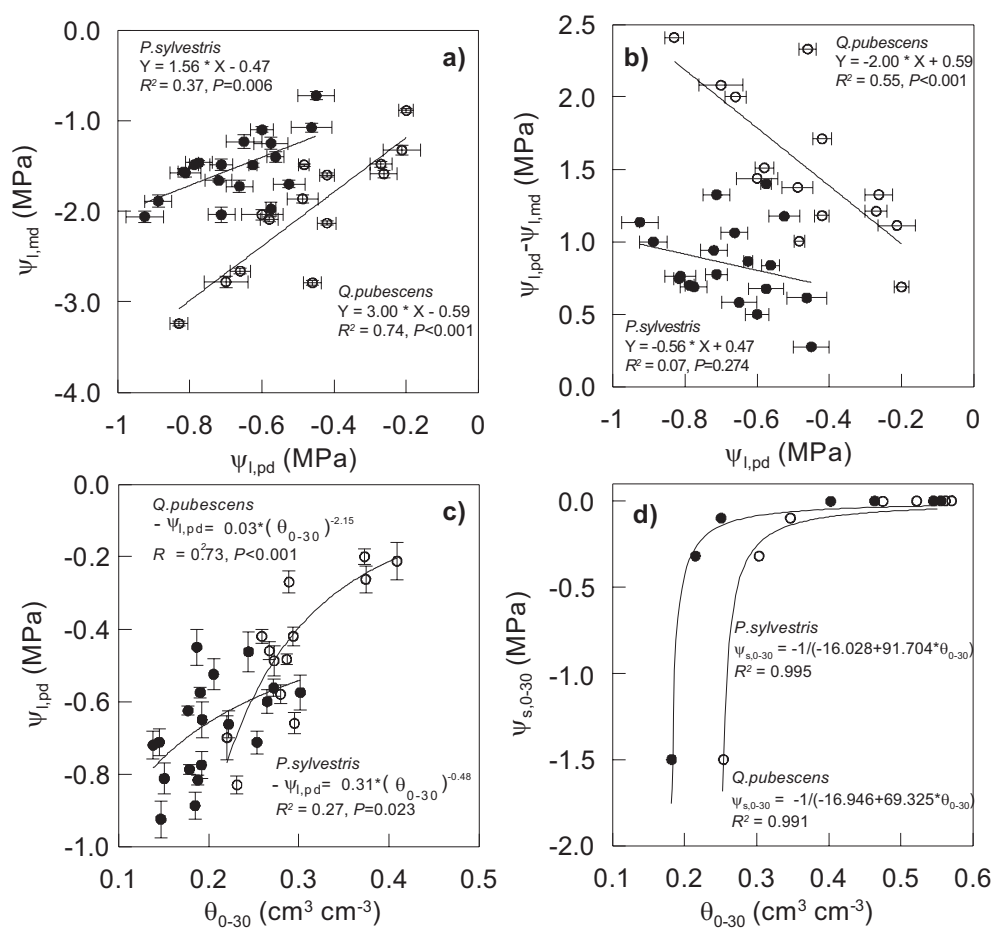

Figure 3. Relationships between (a) predawn $\left(\psi_{1, \mathrm{pd}}\right)$ and midday $\left(\psi_{1, \mathrm{md}}\right)$ leaf water potentials, (b) between water potential difference $\left(\psi_{1, \mathrm{pd}}-\right.$ $\left.\psi_{1, \text { md }}\right)$ and predawn water potential, and (c) between $\psi_{1, \text { pd }}$ and soil moisture in the upper $30 \mathrm{~cm}\left(\theta_{0-30}\right)$. Water retention curves, showing relationships between soil water potential $\left(\psi_{\mathrm{s}, 0-30}\right)$ and $\theta_{0-30}$, are also shown (d). Closed symbols represent data points for $P$. sylvestris and open symbols, for $Q$. pubescens.

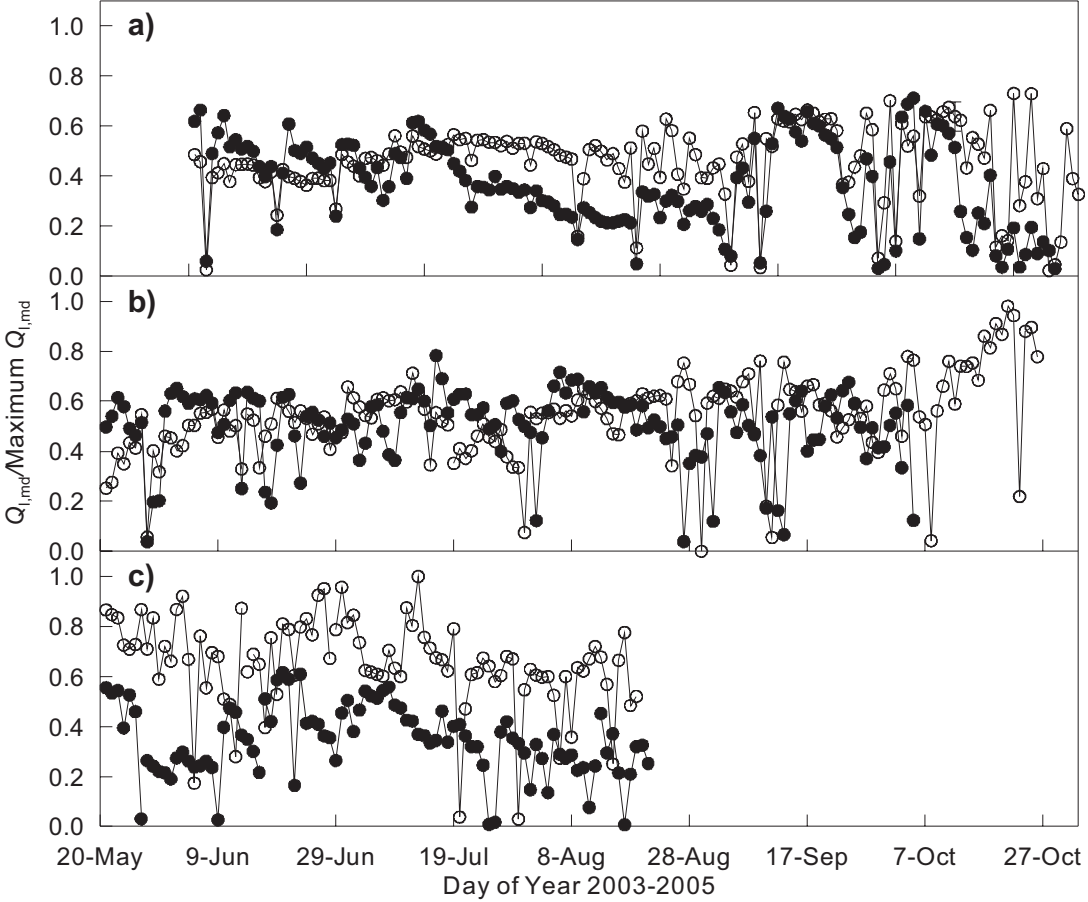

Figure 4. Sap flow per unit leaf area relative to its maximum value for $P$. sylvestris (closed symbols) and $Q$. pubescens (open symbols) during (a) 2003, (b) 2004 and (c) 2005 . 


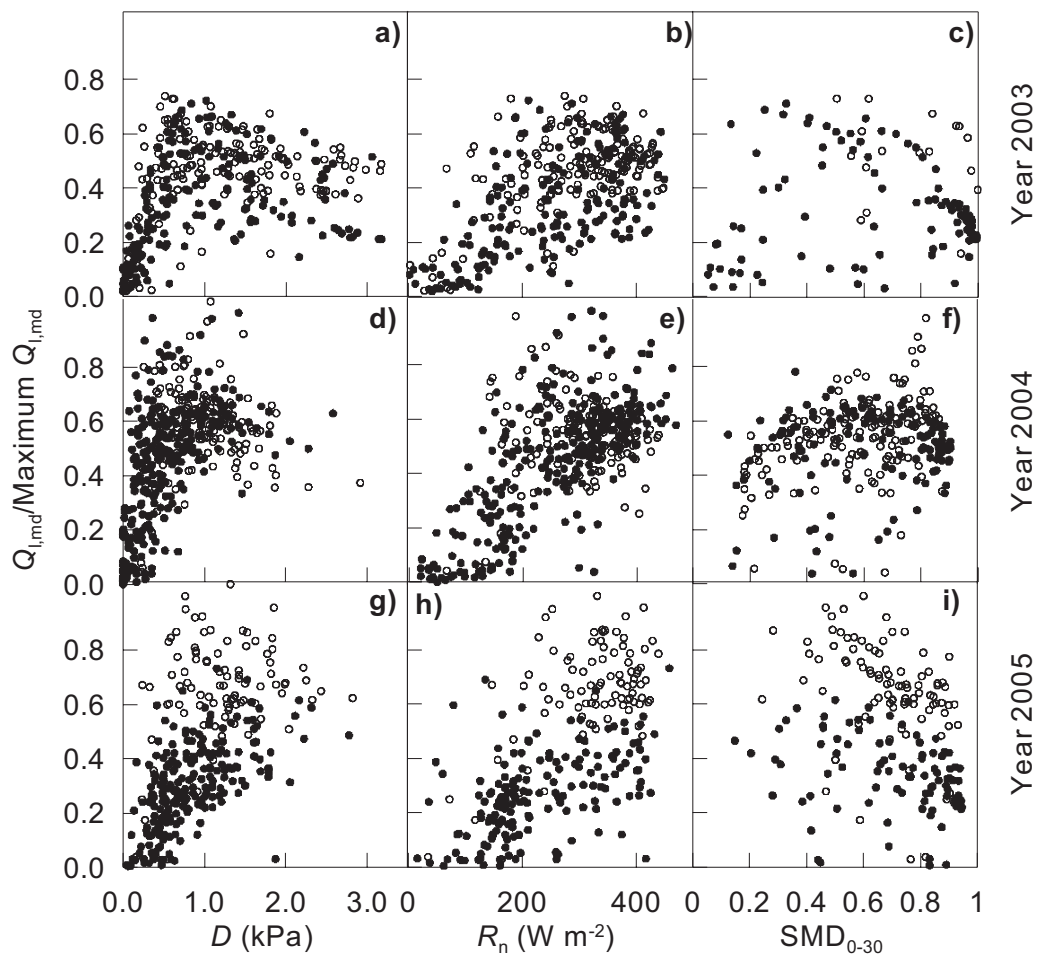

Figure 5. Relationships between relative sap flow and environmental variables for the three years of study for Pinus sylvestris (closed symbols) and Quercus pubescens (open symbols). Panels (a), (d) and (g) show relationships with vapour pressure deficit (D); (b), (e) and (h), with net radiation $\left(R_{\mathrm{n}}\right)$ and $(\mathrm{c}),(\mathrm{f})$ and (i) with superficial soil moisture deficit $\left(\mathrm{SMD}_{0-30}\right)$.

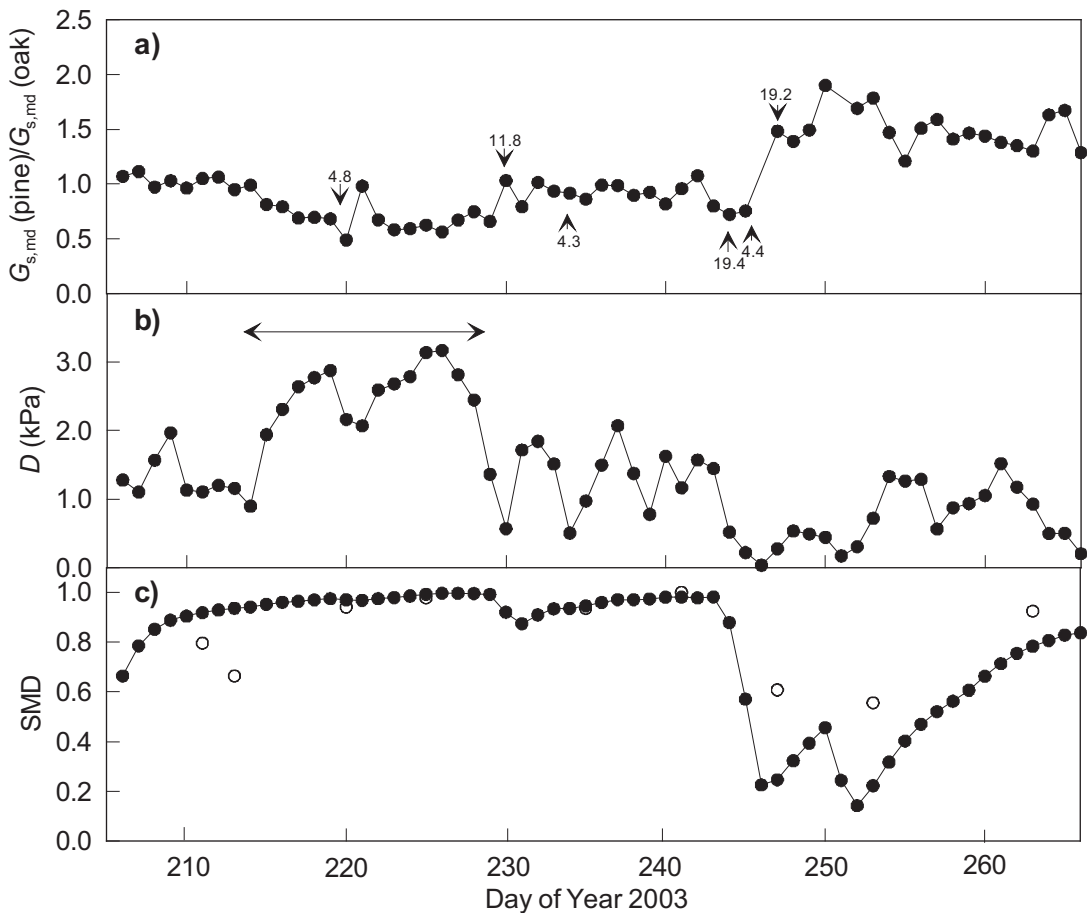

Figure 6. (a) Ratio between pine and oak midday canopy stomatal conductances $\left(G_{\mathrm{s}, \mathrm{md}}\right)$ during the dry episode of the summer of 2003 and posterior recovery. Arrow heads and numbers show rainfall amounts. (b) Corresponding conditions of daytime-averaged vapour pressure deficit $(D)$. The period with extreme $D$ conditions is marked with an horizontal arrow. (c) Soil moisture deficit in the upper soil layer $\left(\mathrm{SMD}_{0-30}\right)$, continuously measured in the pine plot (closed symbols) and fortnightly in the oak plot (open symbols). 


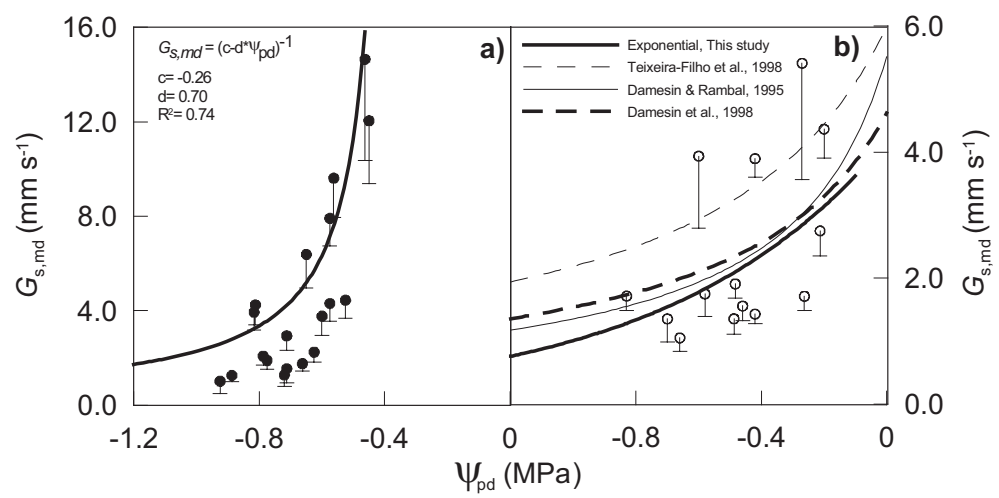

Figure 7. Midday canopy stomatal conductances $\left(G_{\mathrm{s}, \mathrm{md}}\right)$ for (a) Pinus sylvestris and (b) Quercus pubescens related to the value of predawn leaf water potential. The fitted functions are based on Acherar and Rambal (1992), except for the exponential fit used for $Q$. pubescens data in the present study.

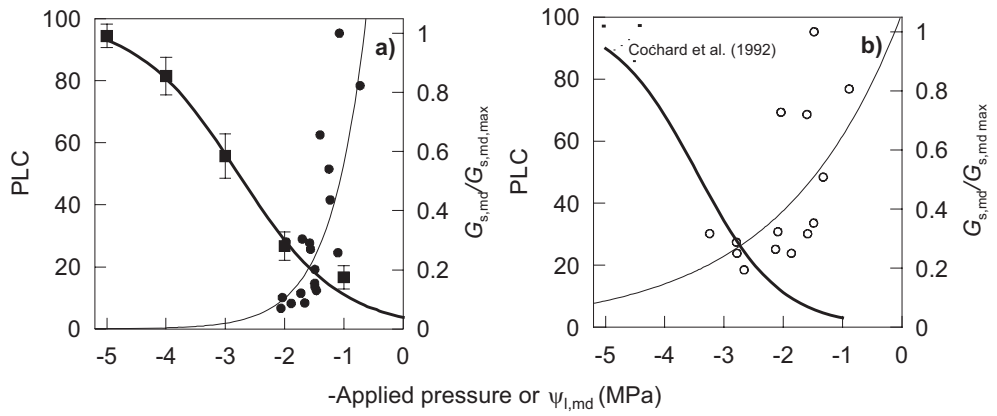

Figure 8. (a) Percent loss of hydraulic conductivity (PLC) for Pinus sylvestris branches with respect to the negative of applied pressure (MPa). The curve was fitted to all the individual measurements of PLC but closed squares are the average of PLC's calculated for $n=10$ branches. The variation of the ratio between midday canopy stomatal conductance $\left(G_{\mathrm{s}, \mathrm{md}}\right)$ and its maximum value $\left(G_{\mathrm{s}, \mathrm{md} \text {, max }}\right)$, and midday leaf water potential $\left(\psi_{1, \mathrm{md}}\right)$ is also shown for P. sylvestris (a) and for $Q$. pubescens (b). For the latter we plotted the vulnerability curve obtained by Cochard et al. (1992) for the same species.

(Fig. 8a). At the same water potentials, Q. pubescens still maintained $G_{\mathrm{s}, \text { md }}$ at $40 \%$ of its maximum value with a corresponding PLC of less than 10\%, according to [9] (Fig. 8b).

Finally, daily maximum values of leaf-level stomatal conductance $\left(g_{\mathrm{s}}\right)$ were closely linked to $k_{\mathrm{L},(\mathrm{s}-1)}$ in both species, following a power relationship for Scots pine and a logarithmic one for pubescent oak (Fig. 9). In addition, a significant relationship was also established between Scots pine PLC predicted by the vulnerability curves and maximum $g_{\mathrm{s}}$ (data not shown).

\section{DISCUSSION}

\subsection{Meteorology, soil moisture and water potentials}

Under similar meteorological conditions, soil moisture in the oak stand was higher than in the pine stand throughout the period of study. Comparisons between long-term soil moisture measurements between the same oak stand and other Scots pine stands in the area show identical results [39]. These differences may be attributed to the different interception characteristics of pine and oak canopies, the role of litterfall preventing direct evaporation from the soil in the deciduous stand, differences in the transpiration component of stand water balance (understorey and overstorey) and intrinsic differences in soil hydraulic properties.

Predawn water potentials were unrelated to estimated soil water potentials in the upper $30 \mathrm{~cm}$ of the soil. As $\psi_{1 \text {, pd }}$ is considered to represent the water potential of the wettest soil layer 'sensed' by the roots [5], our results suggest that trees are exploiting deeper water resources. Indeed, the higher $\psi_{1, \mathrm{pd}}$ in $Q$. pubescens could indicate a more efficient strategy in exploiting soil water resources, especially in depth [45]. We did not find a good correspondence between $\psi_{1 \text {, pd }}$ and $\psi_{\mathrm{s}, 0-30}$ in either species, indicating that $\psi_{\mathrm{s}}$ estimated for the upper $30 \mathrm{~cm}$ was not representative of the whole rooting depth.

Under identical meteorological conditions, more negative leaf water potentials occur in pubescent oak, while for Scots pine, leaf water potentials hardly fall below $-2 \mathrm{MPa}$. While much lower leaf water potentials (ca. $-4.5 \mathrm{MPa}$ ) have been recorded for pubescent oak throughout the Mediterranean region $[14,43]$, the values found for Scots pine are among the lowest ever measured, with the exception of even drier populations in NE Spain [28].

The difference between $\psi_{1, \mathrm{pd}}$ and $\psi_{1, \mathrm{md}}$ increased with decreasing $\psi_{1 \text {,pd }}$ for pubescent oak, therefore allowing a greater increase in the driving force for transpiration as edaphic drought developed. This pattern was not observed in 


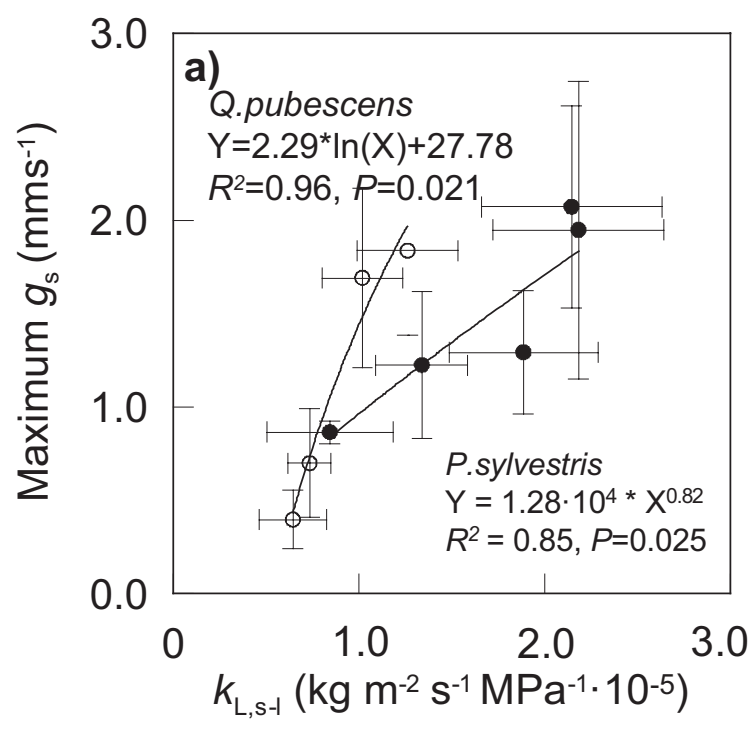

Figure 9. Relationship between maximum stomatal conductance to water vapor measured at the leaf-level $\left(g_{s}\right)$ and whole-plant hydraulic conductance $\left(k_{\mathrm{L}, \mathrm{s}-1}\right)$. (Closed symbols represent $P$. sylvestris and open symbols, $Q$. pubescens).

P. sylvestris, a first indication of an enhanced stomatal control by this species.

\subsection{Sap flow and $G_{s}$ responses to environmental variables and predawn leaf water potential}

We observed that pubescent oak maintained higher sap flow rates during periods with lower soil water availability, such as the summer of 2003 and the year 2005. When soil moisture was not limiting (year 2004), both species showed similar values of relative sap flow but when dry periods occurred (in 2003 and 2005), the enhanced sensitivity of Scots pine sap flow to superficial SMD was clear. We also observed strong responses of relative sap flow in both species to integrated SMD over the soil profile when SMD was larger than 0.6.

High $D$ 's and soil moisture deficits made $G_{s}$ decrease proportionally more in pine than in oak. These findings are in agreement with the general responses of both species to water deficits observed elsewhere. Pubescent oak maintains high transpiration rates despite showing very low leaf water potentials [14, 32], even lower than the turgor loss point [27], while Scots pine efficiently closes stomata beyond a threshold in soil moisture [22] and in response to high vapour pressure deficits [41] .

Scots pine $G_{\mathrm{s}, \mathrm{md}}$, was reduced to $10 \%$ of its maximum value when $\psi_{1 \text {, pd }}$ values approached $-0.8 \mathrm{MPa}$. Perks et al. observed that the ratio between canopy conductance of droughted and control Scots pine trees fell to 0.2 when minimum $\psi_{1, \mathrm{pd}}$ of $-0.8 \mathrm{MPa}$ were reached [35]. Also Sturm et al. [41] showed similar reductions of leaf-level stomatal conductance with decreasing $\psi_{1, \text { pd }}$. However, at the lowest measured $\psi_{1, \mathrm{pd}}$, pubescent oak kept stomatal conductance at higher levels, about $30 \%$ of the maximum value. The relationship between pubescent oak $G_{\mathrm{s} \text {, md }}$ and $\psi_{1 \text {, pd }}$ was similar to others found for the same species [14]. Despite that the absolute values of conductance were higher in another location in Portugal [42], the reduction with $\psi_{1, \text { pd }}$ was also similar to the values that we report.

\subsection{Hydraulic conductance}

Whole-plant hydraulic conductance calculated on a halftotal leaf area basis was higher in Scots pine than in pubescent oak. The values of $P$. sylvestris $k_{\mathrm{L}, \mathrm{s}-1}$ were within the range reported in the literature [3]. The range of $Q$. pubescens $k_{\mathrm{L}, \mathrm{s}-1}$ observed in this study is inferior to published results obtained for saplings of the same species, with $k_{\mathrm{L}, \mathrm{s}-1}$ between 4.5 and $6.5 \cdot 10^{-5} \mathrm{~kg} \mathrm{~m}^{-2} \mathrm{~s}^{-1} \mathrm{MPa}^{-1}$ [27,32]. Values of $k_{\mathrm{L}, \mathrm{s}-1}$ measured in fully-grown Quercus petraea trees from another montane area of the Iberian Peninsula also ranged between 4.0 and $7.0 \cdot 10^{-5} \mathrm{~kg} \mathrm{~m}^{-2} \mathrm{~s}^{-1} \mathrm{MPa}^{-1}[2]$.

Although Scots pine possesses the highest branch-level conductivities among the Pinaceae, typical sapwood conductivities of pines are lower than those of deciduous oak species [7,29]. Published branch-level measurements of $K_{\mathrm{s}}$ in pubescent oak [44] are almost an order of magnitude higher than those found for Scots pine's maximum wood-related conductivity $\left(K_{\mathrm{W}}\right)$ in this study. However, Scots pine has a lower $A_{\mathrm{L}}: A_{\mathrm{S}}$, achieving a higher hydraulic sufficiency than pubescent oak. This compensation mechanism was proposed by Becker et al. [3] to explain the similar hydraulic sufficiency observed between conifers and angiosperms.

We have found that $k_{\mathrm{L}, \mathrm{s}-1}$ was negatively correlated with soil moisture for both species. Accordingly, high levels of $k_{\mathrm{L}, \mathrm{s}-1}$ in Scots pine were only reached during the spring of 2004, before soil moisture deficits developed. Further decreases in $k_{\mathrm{L}, \mathrm{s}-1}$ were observed as the summer progressed in 2005. Our results agree with those of Irvine et al. [22] who found that hydraulic resistance increased significantly for trees under a drought treatment but was maintained essentially constant for control trees.

The decline in $k_{\mathrm{L}, \mathrm{s}-1}$ was clear during 2005 for pubescent oak, in parallel with the increase in superficial and deep SMD. Other authors have reported that, during the summer, wholeplant hydraulic conductance declined up to $50 \%$ of its maximum value in the deciduous Quercus petraea [2]. Consistent with these observations, a maximum of $40 \%$ loss of conductivity at the branch-level has been reported for pubescent oak during mild or slightly dry years $[27,32]$. Nevertheless, maximum conductivity losses of $c a$. $70 \%$ were observed under severe water stress (minimum $\psi_{1, \text { pd }}$ of $-3.6 \mathrm{MPa}$ ) [43].

\subsection{Stomatal control and xylem embolism: coordination of liquid-phase and vapour phase conductances}

The studied Scots pine population was slightly more vulnerable to drought-induced embolism than other populations from drier montane areas of the NE Iberian Peninsula [28], but was more resistant than individuals from Central Europe [11]. 
We found a rapid decline in the fraction of maximum stomatal conductance before significant losses of conductivity occurred in the stem xylem according to the measured vulnerability curve. Irvine et al. [22] also found increases in hydraulic resistance without significant xylem embolisms in the trunk, suggesting an increase in below-ground resistances with drought development. To illustrate the Scots pine's tight stomatal control over xylem embolism, we calculated the safety margin between the water potential causing $10 \%$ loss of conductivity and the water potential reducing stomatal conductance to a $10 \%$ of its maximum. This value was ca. 1.1 MPa, and places Scots pine among the species with strong stomatal control of embolism [6].

Pubescent oak was more resistant to xylem embolism and therefore maintained a higher stomatal opening, with less xylem conductivity losses than Scots pine at a given water potential (Fig. 8). The corresponding safety margin for Q. pubescens would be ca. $3.8 \mathrm{MPa}$. This strategy of keeping large safety margins has been reported for species experiencing seasonal drought episodes [6], in line with the Mediterranean origin of this species. However, these conclusions are drawn from a vulnerability curve which has not been determined in the population we studied, and must be held with caution. A high variability in hydraulic traits among closely-related Submediterranean deciduous oaks has been recently reported in two studies carried out in the Iberian Peninsula $[12,19]$

Finally, we also found a significant correlation between $k_{\mathrm{L}, \mathrm{s}-1}$ and independent measurements of maximum leaf-level $g_{\mathrm{s}}$ in both species (Fig. 9) as observed elsewhere for pine [1] and some angiosperm species [33], but still unreported for oaks. A linear relationship between $g_{\mathrm{s}}$ and $k_{\mathrm{L}, \mathrm{s}-\mathrm{L}}$ has been suggested to be characteristic of isohydric species (regulate $\psi_{1}$ at a constant value), while a curvilinear relationship has been attributed to anisohydric species (intermediate between constant $\psi_{1}$ regulation and no $\psi_{1}$ regulation) [20]. The shape of the relationships between $g_{\mathrm{s}, \max }$ and $k_{\mathrm{L}, \mathrm{s}-\mathrm{L}}$ would imply isohydric and anisohydric behaviour for pine and oak, respectively, as could be also inferred from the seasonal course of leaf water potentials (Fig. 1a, 1b).

\subsection{Implications of the observed responses to water deficits}

Information about the response to water deficits of cooccurring Scots pine and pubescent oak is scarce. Nevertheless, in one recent study both species showed only a slightly higher influence of water deficits in Scots pine, with the largest differences found for dry periods [49]. In general, other studies involving coexisting pine and oak species show that the latter has a more negative threshold $\psi_{1}$ for stomatal closure and a higher $\psi_{\mathrm{pd}}$, meaning greater avoidance of soil water stress [24].

The fact that two contrasting species are able to coexist suggests a significant functional convergence in plant responses to the environment [30]. Nevertheless, extreme drought conditions will definitely affect more negatively the least resis- tant species. In fact, Scots pine populations in the study area showed premature leaf loss during August 2003 and droughtinduced mortality occurred locally in other populations growing at lower elevations at the end of the spring of the year 2005 (personal observation). Besides, drought-induced mortality has been repeatedly observed in Scots pine stand from Mediterranean [28] and Central Europe populations [4]. On the contrary, $Q$. petraea was less affected than other coexisting species by the extreme 2003 summer drought in Central Europe [26].

The distribution of both species in NE Spain support the view that pubescent oak is more adapted to drought, as it can be found from pre-litoral to montane areas, while Scots pine is restricted to the latter. The increased incidence of extreme drought periods in the future [21] is likely to affect Scots pine more severely than pubescent oak, which can bring about significant changes in the composition of Mediterranean montane forests.

\section{CONCLUSIONS}

The overall response to water deficits of the studied Scots pine and pubescent oak under equivalent climatic conditions was similar, but differences appeared when extreme soil moisture deficits and high evaporative demand conditions occur. Pubescent oak showed higher predawn leaf water potentials, which is indicative of a better access to soil moisture. Scots pine showed midday leaf water potentials which were intermediate between those measured in more humid and cooler locations and those observed in drier locations in NE Iberian Peninsula, but generally less negative than the values found for oak. Although both species showed decreasing sap flow beyond a threshold vapour pessure deficit, pubescent oak maintained higher relative sap flow during the intense drought in 2003, and showed less stomatal closure than Scots pine during that period. Midday canopy-averaged stomatal conductance declined in both species with decreasing midday leaf water potentials, but pubescent oak maintained a higher fraction of maximum conductance at the minimum water potentials. Both species showed coordination between leaf-level gas exchange and hydraulic conductance, but. Scots pine showed a tighter stomatal control to avoid substantial hydraulic conductivity losses. Published data on vulnerability to embolism in pubescent oak revealed that it was comparatively more resistant to xylem embolism. We can therefore expect that pubescent oak will be less affected than Scots pine by the predicted increase in aridity in the Mediterranean region.

Acknowledgements: This research was supported by the project CANOA (CGL2004-04919-C02-01) and PROBASE (CGL200611619), funded by the Spanish Ministerio de Educación y Ciencia (MEC). The first author benefited from a predoctoral FPI grant by the MEC The Vallcebre research area also operates with support from the RESEL network through an agreement between the CSIC and DGCONA. The authors are indebted to Juliana Delgado, Francesc Gallart, Xavier Huguet, Jerôme Latron, Núria MartínezCarreras and Montserrat Soler for their help with field data. Romà Ogaya (CREAF) and Josep Matas (Servei de Camps Experimentals, Universitat de Barcelona) are also acknowledged for their helpful 
technical assistance. Jordi Martínez-Vilalta and Antonio Díaz-Espejo provided valuable comments on the manuscript.

\section{REFERENCES}

[1] Addington R.N., Mitchell R.J., Oren R., Donovan L.A., Stomatal sensitivity to vapor pressure deficit and its relationship to hydraulic conductance in Pinus palustris, Tree Physiol. 24 (2004) 561-569.

[2] Aranda I., Gil L., Pardos J.A., Seasonal changes in apparent hydraulic conductance and their implications for water use of European beech (Fagus sylvatica L.) and sessile oak Quercus petraea (Matt.) Liebl. in South Europe, Plant Ecol. 179 (2005) 155167.

[3] Becker P., Tyree M.T., Tsuda M., Hydraulic conductance of angiosperms versus conifers: similar transport sufficiency at the whole-plant level, Tree Physiol. 19 (1999) 445-452.

[4] Bigler C., Bräker O.U., Bugmann H., Dobbertin M., Rigling A., Drought as an inciting mortality factor in scots pine stands of the Valais, Switzerland, Ecosystems 9 (2006) 330-343.

[5] Bréda N., Granier A., Barataud F., Moyne C., Soil water dynamics in an oak stand. I. Soil moisture, water potentials and water uptake by roots, Plant Soil 172 (1995) 17-27.

[6] Bréda N., Huc R., Granier A., Dreyer E., Temperate forest tree and stands under sever drought:a review of ecophysiological responses, adaptation processes and long-term consequences, Ann. Sci. For. 63 (2006) 625-644.

[7] Cavender-Bares J., Holbrook N.M., Hydraulic properties and freezing-induced cavitation in sympatric evergreen and deciduous oaks with contrasting habitats, Plant Cell Environ. 24 (2001) 1243 1256.

[8] Clearwater M.J., Meinzer F.C., Andrade J.L., Goldstein G., Holbrook N.M., Potential erros in measurement of nonuniform sap flow using heat dissipation probes, Tree Physiol. 19 (1999) 681687.

[9] Cochard H., Bréda N., Granier A., Aussenac G., Vulnerability to air embolism of three European oak species (Quercus petraea (Matt) Liebl, Q. pubescens Willd, Q.robur L.), Ann. Sci. For. 49 (1992) 225-233.

[10] Cochard H., Cruiziat P., Tyree M.T., Use of positive pressures to establish vulnerability curves, Plant Physiol. 100 (1992) 205-209.

[11] Cochard H., Cruiziat P., Tyree M.T., Vulnerability of several conifers to air embolism, Tree Physiol. 11 (1992) 73-83.

[12] Corcuera L., Camarero J.J., Sisó S., Gil-Pelegrín E., Radial-growth and wood-anatomical changes in overaged Quercus pyrenaica coppice stands: functional responses in a new Mediterranean landscape, Trees- Struct. Funct. 20 (2006) 91-98.

[13] CREAF, Inventari Ecològic i Forestal de Catalunya. Regió Forestal IV., Bellaterra, Spain, 2000.

[14] Damesin C., Rambal S., Field study of leaf photosynthetic performance by a Mediterranean deciduous oak tree (Quercus pubescens) during a severe summer drought, New Phytol. 131 (1995) 159-167.

[15] DeLucia E.H., Maherali H., Carey E.V., Climate-driven changes in biomass allocation in pines, Glob. Change Biol. 6 (2000) 587-593.

[16] Gallart F., Llorens P., Latron J., Regüés D., Hydrological processes and their seasonal controls in a small Mediterranean mountain catchment in the Pyrenees, Hydrol Earth Syst. Sci. 6 (2002) 527537.

[17] Granier A., Une nouvelle méthode pur la mesure du flux de sève brute dans le tronc des arbres, Ann. Sci. For. 42 (1985) 193-200.
[18] Granier A., Loustau D., Measuring and modelling the transpiration of a maritime pine canopy from sap-flow data, Agric. For. Meteorol. 71 (1994) 61-81.

[19] Himrane H., Camarero J.J., Gil-Pelegrín E., Morphological and ecophysiological variation of the hybrid oak Quercus subpyrenaica $(Q$. faginea $\times Q$. pubescens), Trees 18 (2004) 566-575.

[20] Hubbard R.M., Ryan M.G., Stiller V., Sperry J.S., Stomatal conductance and photosynthesis vary linearly with plant hydraulic conductance in ponderosa pine, Plant Cell Environ. 24 (2001) 113-121.

[21] IPCC, Climate Change 2001: The Scientific Basis: Contribution of Working Group I to the Third Assessment Report of the Intergovernmental Panel on Climate Change (IPCC), Cambridge University Press, Cambridge, UK, 2001.

[22] Irvine J., Perks M.P., Magnani F., Grace J., The response of Pinus sylvestris to drought: stomatal control of transpiration and hydraulic conductance, Tree Physiol. 18 (1998) 393-402.

[23] Jalas J., Suominen J., R. L., Atlas Florae Europaeae, in: http://www.helsinki.fi/kmus/afe.html (Ed.), 1999.

[24] Kolb T.E., Stone J.E., Differences in leaf gas exchange and water relations among species and tree sizes in an Arizona pine-oak forest, Tree Physiol. 20 (1999) 1-12.

[25] Latron J., Soler M., Llorens P., Gallart F., Spatial and temporal variability of the hydrological response in a small Mediterranean research catchment (Vallcebre, Eastern Pyrenees), Hydrol. Process 25 (2007) 775-787.

[26] Leuzinger S., Zotz G., Asshoff R., Körner C., Responses of deciduous forest trees to severe drought in Central Europe, Tree Physiol. 25 (2005) 641-650.

[27] Lo Gullo M.A., Salleo S., Rosso R., Trifilo P., Drought resistance of 2-year-old saplings of Mediterranean forest trees in the field: Relations between water relations, hydraulics and productivity, Plant Soil 250 (2003) 259-272.

[28] Martínez-Vilalta J., Piñol J., Drought-induced mortality and hydraulic architecture in pine populations of the NE Iberian Peninsula, For. Ecol. Manage. 161 (2002) 247-256.

[29] Martínez-Vilalta J., Sala A., Piñol J., The hydraulic architecture of Pinaceae - a review, Plant Ecol. 171 (2004) 3-13.

[30] Meinzer F.C., Functional convergence in plant responses to the environment, Oecologia 134 (2003) 1-11.

[31] Nadezhdina N., Čermák J., Nadezhdin V., Heat field deformation method for sap flow measurements, in: Èermák J., Nadezhdina N. (Eds.), 4th International Workshop on Measuring Sap Flow in Intact Plants, IUFRO Publications, Zidlochovice, Czech Republic, 1998, pp. 72-92.

[32] Nardini A., Pitt F., Drought resistance of Quercus pubescens as a function of root hydraulic conductance, xylem embolism and hydraulic architecture, New Phytol. 143 (1999) 485-493.

[33] Nardini A., Salleo S., Limitation of stomatal conductance by hydraulic traits: sensing or preventing cavitation? Trees 15 (2000) $14-24$.

[34] Pallardy S.G., Čermák J., Ewers F.W., Kaufmann M.R., Parker W.C., Sperry J.S., Water transport dynamics in trees and stands, in: Smith W.K., Hinckley T.M. (Eds.), Resource physiology of conifers, Academic Press, San Diego, 1995, pp. 301-389.

[35] Perks M.P., Irvine J., J.Grace, Canopy stomatal conductance and xylem sap abscisic acid (ABA) in mature Scots pine during a gradually imposed drought, Tree Physiol. 22 (2002) 877-883.

[36] Poyatos R., Čermák J., Llorens P., Variation in the radial patterns of sap flux density in pubescent oak (Quercus pubescens Willd.) and its implications for tree and stand transpiration measurements, Tree Physiol. 27 (2007) 537-548. 
[37] Poyatos R., Latron J., Llorens P., Land-use and land cover change after agricultural abandonment. The case of a Mediterranean Mountain Area (Catalan Pyrenees), Mt. Res. Dev. 23 (2003) 52-58.

[38] Richardson L.A., Pressure membrane apparatus: construction and use, Agricultural Engineering 28 (1947) 451-454.

[39] Rubio Esteve C., Hidrodinámica de los suelos de un área de montaña media mediterránea sometida a cambios de uso y cubierta, Ph.D. thesis, Universitat Autònoma de Barcelona, Barcelona, Spain, 2005, $194 \mathrm{p}$.

[40] Stenberg P., Linder S., Smolander H., Flower-Ellis J., Performance of the LAI-2000 plant canopy analyzer in estimating leaf area index of some Scots pine stands, Tree Physiol. 14 (1994) 981-995.

[41] Sturm N., Köstner B., Hartung W., Tenhunen J.D., Environmental and endogenous controls on leaf- and stand-level water conductance in a Scots pine plantation, Ann. Sci. For. 55 (1998) 237-253.

[42] Teixeira-Filho J., Damesin C., Rambal S., Joffre R., Retrieving leaf conductances from sap flows in a mixed mediterranean woodland: a scaling exercise, Ann. Sci. For. 55 (1998) 173-190.

[43] Tognetti R., Longobucco A., Raschi A., Vulnerability of xylem to embolism in relation to plant hydraulic resistance in Quercus pubescens and Quercus ilex co-occurring in a Mediterranean coppice stand in central Italy, New Phytol. 139 (1998) 437-447.
[44] Tognetti R., Longobucco A., Raschi A., Seasonal embolism and xylem vulnerability in deciduous and evergreen Mediterranean trees influenced by proximity to a carbon dioxide spring, Tree Physiol. 19 (1999) 271-277.

[45] Valentini R., Scarascia Mugnozza G.E., Ehleringer J.R., Hydrogen and carbon isotope ratios of selected species of a Mediterranean macchia ecosystem, Funct. Ecol. 6 (1992) 627-631.

[46] Villar-Salvador P., Castro-Díez P., Pérez-Rontomé C., MontserratMartí G., Stem xylem features in three Quercus (Fagaceae) spp. along a climatic gradient in NE Spain, Trees 12 (1997) 90-96.

[47] Warren J.M., Meinzer F.C., Brooks J.R., Domec J.C., Vertical stratification of soil water storage and release dynamics in Pacific Northwest coniferous forests, Agric. For. Meteorol. 130 (2005) 39-58.

[48] Whitehead D., Jarvis P.G., Coniferous forests and plantations, in: Kozlowski T.T. (Ed.), Water Deficits and Plant Growth, Academic Press, New York, 1981, pp. 49-152.

[49] Zweifel R., Zimmerman L., Newberry D.M., Modelling tree water deficit from microclimate: an approach to quantifying drought water stress, Tree Physiol. 25 (2005) 147-156. 